\title{
THE MINI-WRIGHT EXPIRATORY PEAK FLOW METER
}

\author{
Eileen Levin and Martin I. Gold
}

\begin{abstract}
The purpose of this study was to compare the recently modified mini-Wright peak flow meter with the Wright peak flow meter. One hundred adult patients were arbitrarily divided into two groups, based on their average peak flow on the mini-Wright device. A strong positive correlation in excess of 0.90 was shown. We believe that the smaller, cheaper device is as accurate as the Wright peak flow meter.
\end{abstract}

KEy WORdS: EQUIPMENT, VENTILATION, MONITORING; expiratory flow meter, MEASUREmEnt TEChNiques, respirometry.

The evaluation of pulmonary function in the preoperative patient with lung disease varies from the match test ${ }^{1}$ to sophisticated spirometric testing and dilutional determinations of lung volume. ${ }^{2}$ The measurement of peak flow during a maximally forced exhalation - a sensitive, though non-specific measure of decreased expiratory air flow - has not been popular in the United States, ${ }^{3}$ yet peak flow has correlated well with many of the standard indices of airflow obstruction. ${ }^{4.5}$

The Wright peak flow meter ${ }^{6}$ has been in use for several decades. Recently, a smaller, lightweight and considerably cheaper device was released for the quantitative bedside assessment of airflow - the mini-Wright peak flow meter? Since its initial evaluation ${ }^{8}$ the manufacturer* has modified the scale of flow values. $\dagger$ This study compared the modified mini-Wright instrument with the original Wright device.

\section{Methods AND Materials}

Devices used in this study have been described previously. ${ }^{6-8}$

Instrument variation was assessed before comparing the flow meters. Nine subjects were

Eileen Levin, M.D., Research Fellow and Resident in Anesthesiology; Martin I. Gold, M.D., Professor of Anesthesiology; Department of Anesthesiology, University of Miami School of Medicine, and the Miami Veterans Administration Medical Center, 1201 N.W. 16th Street, Miami, Florida 33125, U.S.A.

Reprint requests to: Martin I. Gold, M.D., Miam Veterans Administration Medical Center, 1201 N.W. 16th Street, Miami, Florida 33125, U.S.A.

*Armstrong Industries Incorporated; Northbrook, Illinois 60062

$\dagger$ This was done by increasing the linear distance between scales. 285 assigned randomly to one of each of the six mini-Wright devices on subsequent days at the same time each day; each instrument was used once by each subject and three measurements were made each day. A similar assessment of instrument variation was made with the two Wright peak flow meters.

After obtaining institutional approval and informed consent, measurements of peak expiratory flow were made with subjects in the sitting position and without nose clips. After appropriate instruction, subjects were given one "practice" peak flow (or more, if necessary) into one of each type of instrument. Six maximally forced exhalations were then measured. Patients alternated between two instruments - a total of three readings per device - the first instrument determined by assignment from a table of random numbers. ${ }^{9}$ Vigorous subjects completed the sequence as quickly as tolerated; "borderline" subjects were given appropriate recovery time between measurements. All subjects exhaled through disposable mouth-pieces into the flow meters. The highest and the average of the three peak flow measurements on each instrument were used for comparison.

One hundred and fifteen adult subjects were measured consecutively until 50 subjects were assigned, arbitrarily, to each of two groups, based on their average peak flows on the miniWright device. Group I included those with peak flows greater than $350 \mathrm{l} / \mathrm{min}$; group II less than $350 \mathrm{l} / \mathrm{min}$. Six new mini-Wright and two recently calibrated Wright peak flow meters were used.

The highest and the average of three measurements from each of the two groups of subjects were analyzed by paired ' $t$ ' test; correlation coefficients were derived from regression curves. 


\section{TABLE I}

Group I: Highest and Average Values for Wright and Mini-Wright PEAK Flow Meter

\begin{tabular}{lrr}
\hline & Wright & Mini-Wright \\
\hline Highest Vialues & & \\
mean \pm S.D. (1/min) & $514.4 \pm 98.3$ & $514.9 \pm 88.0$ \\
$\quad$ Correlation coefficient 0.95 & \\
Average Values & \\
mean \pm S.D. (1/min) & $500.6 \pm 93.4$ & $501.5 \pm 89.0$ \\
$\quad$ Correlation coefficient 0.96 & \\
all differences statistically insignificant \\
\hline
\end{tabular}

TABLE II

Group II: Highest and AVERAge Values for Wright and Mini-Wright Peak Flow Meter

\begin{tabular}{lcr}
\hline \hline & Wright & Mini-Wright \\
\hline Highest Values* & & \\
mean \pm S.D. (1/min) & $219.5 \pm 77.0$ & $242.2 \pm 74.2$ \\
Correlation coefficient 0.91 & \\
mean difference 95\% confidence limits & $16.6-34.81 / \mathrm{min}$
\end{tabular}

Average Values*

Mean \pm S.D. (1/min) $\quad 203.9 \pm 70.0 \quad 226.5 \pm 70.3$

Correlation coefficient 0.92

mean difference $95 \%$ confidence limits $14.7-30.51 / \mathrm{min}$

${ }^{*}(\mathrm{p}<0.05)$.

Instrument variation was assessed by analysis of variance. For all forms of statistical analysis, a $p$ value of 0.05 or less was the criterion of significance.

\section{RESULTS}

There was no between-machine variation for the six mini-Wright devices (F-ratio 0.0154 with five and 48 degrees of freedom, $p>0.05$ ). We accepted the 3-4 per cent difference between the two Wright peak flow devices found at the termination of the study, although no difference was found at the outset.

Participants included volunteers from operating room personnel such as nurses, residents, and in-patients with pulmonary dysfunction or heavy smoking histories (75 pack-years and greater) chosen from the medical and surgical wards and outpatients seen in the Pulmonary Clinic. Participants were measured consecutively until fifty were included in each of the two groups. Data from 15 subjects unable to complete the sequential measurements were discarded.

Group I (average peak flows on the mini-
Wright device $>350 \mathrm{l} / \mathrm{min}$ ), showed no significant differences between the two instruments when either the highest or the average of three peak flow measurements were compared (Table I).

Statistically significant differences were seen between the instruments in Group II (Table II). The mean difference and 95 per cent confidence limits in favour of the mini-Wright device was $22.6 \pm 7.9 \mathrm{l} / \mathrm{min}$ when average values were compared and $25.7 \pm 9.1 \mathrm{l} / \mathrm{min}$ when highest peak flows were compared.

\section{Discussion}

The results of this study show that the modified mini-Wright peak flow meter is as accurate and reliable as the original Wright device. No differences were found between the two instruments for flow values above $350 \mathrm{l} / \mathrm{min}$; the statistically significant difference in favour of the mini-Wright device for flow values less than $350 \mathrm{l} / \mathrm{min}$ correspond to only slightly more than 10 per cent error in actual peak flow measured. The practical importance of such a small difference is minimal.

We arbitrarily chose the manufacturer's steady-state flow calibration point $(350 \mathrm{l} / \mathrm{min})$ to evaluate the instrument's high range and low range. Before modifications were made to the adhesive strip of flow values the mini-Wright peak flow meter was shown by Perks, et al. in a similar study ${ }^{8}$ to have a constant deviation of $+38 \mathrm{l} / \mathrm{min}$ over its entire range compared to the Wright device; our data (based on the modilied device) demonstrate that this has been reduced by more than half.

Wright peak flow meters, newly calibrated, have been shown to vary one from another by about five per cent of the average peak flow reading; consequently the use of this device may be unjustified in comparative trials when more than one instrument is utilized and differences less than five per cent are being sought. ${ }^{10} \mathrm{How}$ ever, for clinical studies such as this its ease of handling, portability and relative accuracy make it a practical choice for comparative testing, providing that instrument variations are specified. No statistically significant difference was noted between the two Wright peak flow meters at the beginning of our study. Moreover, we measured no statistically significant instrument variation in the six mini-Wright devices in contrast to the variation (F-ratio 3.67 with 9 and 81 degrees of freedom, $p<0.001$ ) seen in the prior study. ${ }^{8}$ 
In this era of cost-containment the availability of an inexpensive, non-invasive, compact, pocket-type peak flow meter for the preoperative bedside assessment of the patient with obstructive pulmonary disease is welcome.

\section{REFERENCES}

I. OLSEN, C.R. The match test: a measure of ventilatory function. Am. Rev. Respir. Dis. 86: 37-40 (1962).

2. Bergman, N.A. New tests of pulmonary function: physiologic basis and interpretation. Anesthesiology 44: 220-229 (1976).

3. Williams, M.H. Evaluation of asthma. Chest $I$ 3-4 (1979).

4. Leiner, G.C., Abramowitz, S., Small, M.J. STENBY, V.B. \& LEWIS, W.A. Expiratory peak flow rate. Am. Rev. Respir. Dis. 88: 644-651 (1963).

5. Ritchie, B. A comparison of forced expiratory volume and peak flow in clinical practice. Lancet 2 : 271-273 (1962).

6. Wright, B.M. \& MCKerrow, C.B. Maximum forced expiratory flow rate as a measure of ventilatory capacity. Br. Med. J. 2: 1041-1047 (1959).

7. WRIGHT, B.M. A miniature Wright peak-flow meter. Br. Med. J. 2: 1627-1628 (1978).

8. Perks, W.H., Tams, I.P., Thompson, D.A. \& ProwsE, K. An evaluation of the mini-Wright peak flow meter. Thorax 34: 79-81 (1979).

9. SNedecor, G.W. \& Cochran, W.G. Statistical methods. 6th Ed. Ames, lowa, lowa State University Press. 1967.

10. Altman, D.G., Irwig, L.M. \& Jagdish, V. A trial of the comparability of peak expiratory flow meters in school children. Bull europ. Physiopath. resp. 13: 281-284 (1977).

\section{RÉSUMÉ}

L'objectif de cette étude était de comparer le mini débitmètre de pointe de Wright tel que modifié récemment avec le débitmètre de pointe de Wright. Cent patients d'âge adulte furent divisés en deux groupes de façon arbitraire selon leur débit expiratoire de pointe moyen tel que mesuré par le mini-appareil de Wright. Une correlation positive importante dépassant 0.90 a été montrée et nous croyons que ce nouvel appareil qui est plus petit et coûte moins cher, est aussi précis que le débitmètre de pointe de Wright. 